\title{
PENINGKATAN PRESTASI BELAJAR PAI MATERI WUDHU MELALUI METODE DEMONSTRASI PADA SISWA KELAS II SEKOLAH DASAR
}

\author{
Wijiati \\ Guru SDN 1 Sukadana
}

\begin{abstract}
Abstrak: Penelitian ini bertujuan untuk mengetahui metode demonstrasi dapat meningkatkan prestasi belajar siswa dengan materi wudhu pada siswa kelas II SDN 1 Sukadana Tahun 2017. Penelitian tindakan kelas ini menggunakan metode demonstrasi dengan cara memperagakan atau mempertunjukkan kepada siswa suatu proses, situasi yang sedang dipelajari sehingga proses penerimaan siswa terhadap pelajaran akan lebih berkesan secara mendalam. Penelitian ini merupakan PTK dengan 3 siklus melalui 4 tahapan yaitu perencanaan, pelaksanaan, observasi dan refleksi. Subyek penelitian ini sebanyak 32 siswa. Hipotesis yang diajukan adalah jika metode demonstrasi dapat digunakan dengan baik dapat meningkatkan prestasi belajar siswa mata pelajaran PAI pada siswa kelas II SDN 1 Sukadana Tahun 2017. Indikator keberhasilan 75\% dengan KKM sebesar 75. Teknik pengumpulan data dengan observasi.Teknik analisis data dengan rumus untuk mengetahui nilai rata-rata dan presentase. Hasil penelitian menunjukkan bahwa prestasi belajar pada siklus I sebesar 44\% atau 14 siswa dengan KKM 75, siklus II sebesar 56\% atau 18 siswa dengan KKM 75 dan pada siklus III sebesar $81 \%$ atau 26 siswa untuk materi rukun wudhu dan sebesar 87,5\% atau 28 siswa untuk materi sunah wudhu dengan KKM 75. Peningkatan prestasi belajar siswa pada siklus I ke siklus II sebesar 12\% dengan KKM 75, peningkatan prestasi pada siklus II ke siklus III dengan materi rukun wudhu sebesar $25 \%$ dan pada materi sunah wudhu sebesar 31,5\%.
\end{abstract}

Kata Kunci: Prestasi Belajar dan Metode Demonstrasi

\section{PENDAHULUAN}

Pendidikan merupakan sarana yang sangat strategis dalam melestarikan sistem nilai yang berkembang dalam kehidupan. Sistem nilai tersebut meliputi ranah pengetahuan, kebudayaan maupun nilai keagamaan. Proses pendidikan tidak hanya memberikan pengetahuan dan pemahaman kepada peserta didik, namun lebih diarahkan pada pembentukan sikap, perilaku, dan kepribadian anak.

Tugas pendidik dalam konteks ini membantu mengkondisikan peserta didik pada sikap, perilaku atau kepribadian yang benar agar mampu berkembang dan berguna bagi dirinya dan masyarakat. Pelaksanaan pembelajaran harus mampu membantu peserta didik agar menjadi manusia yang berbudaya tinggi dan bermoral tinggi. Untuk mewujudkan capaian tersebut salah satu cara yang bisa dilakukan oleh seorang guru adalah dengan melaksanakan pembelajaran yang inovatif.

Selama ini proses pembelajaran yang dilaksanakan oleh peneliti dinilai masih monoton. Hal ini terlihat pada pemilihan metode, alat peraga maupun model pembelajaran serta hasil yang dicapai oleh peserta didik masih rendah. Materi praktek wudhu tidak mungkin hanya dengan ceramah menyebabkan siswa kurang memahami materi tersebut, maka dipilih model yang bervariasi seperti metode demonstrasi, diharapkan dengan metode demonstrasi peserta didik dapat 
memahami sekaligus mempraktikkannya secara langsung.

Ada dua aspek penilaian dalam mata pelajaran Pendidikan Agama Islam, yaitu aspek teori dan aspek praktik. Kedua aspek tersebut memiliki bobot nilai yang sama. Bahkan menurut penulis aspek kemampuan praktik pada mata pelajaran Pendidikan Agama Islam sangat penting daripada teori. Pendapat ini berdasarkan alasan bahwa kemampuan praktik akan diaplikasikan dalam kehidupan seharihari, khususnya wudhu.

Wudhu merupakan perbuatan yang disyaratkan dengan tegas berdasarkan beberapa dalil sesuai dengan firman Allah SWT:

"Hai orang-orang yang beriman, apabila kamu hendak mengerjakan shalat,maka basuhlah mukamu dan tanganmu sampai dengan siku, dan sapulah kepalamu dan (basuh) kakimu sampai dengan kedua mata kaki, dan jika kamu junub maka mandilah, dan jika kamu sakit atau dalam perjalanan atau kembali dari tempat buang air (kakus) atau menyentuhperempuan, lalu kamu tidak memperoleh air, maka bertayammumlah dengan tanah yang baik (bersih); sapulah mukamu dan tanganmu dengan tanah itu. Allah tidak hendak menyulitkan kamu, tetapi Dia hendak membersihkan kamu dan menyempurnakan nikmat-Nya bagimu, supaya kamu bersyukur".(Al-Ma'idah: 6).

Dalil kedua, sunah dari Abu Hurairoh r.a. bahwa Nabi SAW. Bersabda :"Allah tidak menerima sholat yang dikerjakan salah seorang diantaramu bila ia berhadats, sehingga berwudhu terlebih dahulu." Al-Hadist: HSR (Hadist Sahih Riwayat) Bukhary-Fathul Baary, I:206 ; Muslim, no. 225). Kondisi peserta didik di SDN 1 Sukadana kelas dua sekarang ini memiliki kemampuan praktik wudhu yang masih rendah. Dahulu menggunakan metode klasik yaitu metode ceramah. Selama proses pembelajaran $10 \%$ siswa dari 32 anak bermain sendiri, $30 \%$ siswa mengantuk, $30 \%$ siswa kurang memperhatikan dan $30 \%$ siswa kurang aktif. Berdasarkan fenomena tersebut, penggunaan metode ceramah perlu dilakukan variasi dengan menggunakan metode lain antara lain dengan metode demonstrasi. Dalam kompetensi dasar tentang praktik wudhu ini peneliti sengaja menggunakan dua kriteria keberhasilan yaitu berhasil baik dan belum berhasil.

Berdasarkan pada fenomena tersebut, pembelajaran materi wudhu dengan menggunakan metode demonstrasi untuk meningkatkan prestasi belajar perlu dilakukan melalui Penelitian Tindakan Kelas, peneliti menentukan judul: Peningkatan Prestasi Belajar PAI Materi Wudhu Melalui Metode Demonstrasi Pada Siswa Kelas II SDN 1 Sukadana Kec. Sukadana Kab. Kayong Utara Tahun 2017. Dengan rumusan masalah apakah metode demonstrasi dapat meningkatkan prestasi belajar siswa pada materi wudhu pada siswa.

Penelitian ini bertujuan untuk mengetahui metode demonstrasi dapat meningkatkan prestasi belajar. Dengan dilakukannya penelitian tindakan kelas ini diharapkan akan berguna bagi berbagai pihak yang terkait dengan kegiatan pembelajaran khususnya mata pelajaran Pendidikan Agama Islam, diantara yang memperoleh manfaat itu

Prestasi berasal dari bahasa Belanda yaitu "prestatie" sedang dalam kamus Bahasa Indonesia menjadi "prestasi" yang berarti "hasil usaha" (Arifin, 2002:2). Prestasi adalah hasil yang telah dicapai dari yang telah dikerjakan atau dilakukan (Depdiknas, 2007:895). Kehadiran prestasi belajar dalam kehidupan manusia pada tingkat dan jenis tertentu dapat memberikan kepuasan tertentu pada manusia.

Dalam kamus besar Bahasa Indonesia, belajar memiliki arti berusaha memperoleh kepandaian atau ilmu. Belajar adalah suatu proses usaha yang dilakukan individu untuk memperoleh suatu perubahan tingkah laku yang baru secara keseluruhan, sebagai hasil 
pengalaman individu itu sendiri dalam interaksi dengan lingkungannya (Slameto, 1991:2).

Menurut Syah (1995:89) Belajar adalah kegiatan yang berproses dan merupakan unsur yang sangat fundamental dalam setiap penyelenggaraan jenis dan jenjang pendidikan.

Berdasarkan pendapat di atas penulis menyimpulkan bahwa belajar adalah suatu proses perubahan tingkah laku sebagai hasil dari interaksi (hubungan) dengan lingkungan dalam memenuhi kebutuhan hidupnya. Menurut Djamarah (1997:102103) metode demonstrasi adalah cara penyajian bahan pembelajaran dengan meragakan atau mempertunjukkan kepada siswa suatu proses, situasi, atau benda tertentu yang sedang dipelajari, baik sebenarnya ataupun tiruan, yang sering disertai dengan penjelasan lisan. Dengan metode demonstrasi, proses penerimaan siswa terhadap pelajaran akan lebih berkesan secara mendalam, sehingga membentuk pengertian dengan baik dan sempurna. Juga siswa dapat mengamati dan memperhatikan apa yang diperlihatkan selama pelajaran berlangsung.

Setelah segala sesuatu direncanakan dan dipersiapkan, langkah berikutnya adalah mulai melaksanakan demontrasi. Beberapa hal yang perlu diperhatikan antara lain (1) Sebelum memulai, periksalah sekali lagi kesiapan peralatan yang akan didemontrasikan, tempat dan pokok-pokok yang akan didemonstrasikan. (2) Siapkanlah siswa, barang kali ada beberapa hal yang perlu dicatat. (3) Mulailah demonstrasi dengan menarik perhatikan siswa, ingat pokokpokok materi yang akan didemonstrasikan agar dapat mencapai sasaran. (4) Ingatlah pokok-pokok materi yang akan disampaikan agar demontrasi mencapai sasaran. (5) Pada waktu berjalannya demonstrasi, sekali-kali perhatikan keadaan siswa apakah semua mengikuti dengan baik. (6) Untuk menghindari ketegangan ciptakan suasana yang harmonis. (7) Berikanlah kesempatan kepada siswa untuk secara aktif memikirkan lebih lanjut tentang apa yang dilihat dan didengar.

Menurut Djamarah (1997:104) kekurangan metode demonstrasi adalah : (1) Metode ini memerlukan keterampilan guru secara khusus, karena tanpa ditunjang hal itu, pelaksanaan demonstrasi akan tidak efektif. (2) Fasilitas seperti peralatan, tempat, dan biaya yang memadai tidak selalu tersedia dengan baik. Demonstrasi memerlukan kesiapan dan perencanaan yang matang disamping memerlukan waktu yang cukup panjang, yang mungkin terpaksa mengambil waktu atau jam pelajaran lain.

\section{METODE}

Penelitian ini menggunakan penelitian tindakan kelas. Prosedur dan langkah langkah penelitian mengikuti prinsip-prinsip dasar yang berlaku dalam PTK merupakan suatu pencermatan terhadap kegiatan yang sengaja dimunculkan dan terjadi dalam sebuah kelas (Aqib, 2006:13). Adapun tujuan Penelitian Tindakan Kelas (PTK) adalah : (1) Peningkatan dan perbaikan praktik pembelajaran. (2) Meningkatkan mutu isi, masukan, proses, serta hasil pendidikan dan pembelajaran di sekolah. (3) Membantu guru dan tenaga kependidikan lainnya mengatasi masalah pembelajaran dan pendidikan di dalam kelas. (4) Meningkatkan sikap profesional pendidik dan tenaga kependidikan. (5) Menumbuhkembangkan budaya akademik di lingkungan sekolah sehingga tercipta sikap proaktif di dalam melakukan perbaikan mutu. (6) pendidikan dan pembelajaran secara berkelanjutan (sustainable).

Tahap-tahap dalam Penelitian Tindakan Kelas (PTK) terdiri dari empat tahapan penting, meliputi ; (1) planning (perencanaan), (2) Action (tindakan), (3) 
Observation (pengamatan) dan (4) Reflection (refleksi) (Arikunto, 2006:20).

Penelitian ini dilaksanakan di SDN 1 Sukadana, Kecamatan Sukadana Kabupaten Kayong Utara. Pada siswa kelas II yang berjumlah 32 siswa.

Kegiatan evaluasi yang dilakukan oleh guru untuk mengukur keberhasilan program pengajaran dan untuk mengukur prestasi peserta didik tentang mata pelajaran Pendidikan Agama Islam khususnya pada pada pokok bahasan Praktik Wudhu. Sebuah lembar untuk mengamati guru dan siswa pada waktu pembelajaran berlangsung.

Pengumpulan data dan Observasi. Observasi digunakan untuk mendapatkan data tentang perubahan yang terjadi selama proses pembelajaran berlangsung.

\section{HASIL PENELITIAN DAN}

PEMBAHASAN

Hasil Penelitian

Siklus I

\section{Perencanaan}

Peneliti

penyusun RPP.

Mempersiapkan fasilitas dan sarana pendukung. Menyiapkan. Lembar observasi kegiatan guru dan lembar observasi kegiatan peserta didik.

\section{Pelaksanaan}

Guru mengajak siswa untuk membaca doa berwudhu secara bersamasama.2)Guru membagi menjadi 8 kelompok, setiap kelompok terdiri dari 4 orang dan diminta untuk memperhatikan contoh-contoh gerakan rukun wudhu. 3)Guru melakukan tanya jawab tentang rukun wudhu.

\section{Observasi}

Dengan instrumen yang telah disiapkan peneliti dan 3 kolaborator yaitu Ibu Mahmudah, Ibu Ratna Baroroh dan Ibu Asyiah untuk melakukan pengamatan atau observasi. Hal-hal yang diamati yakni: (1) Lembar observasi kegiatan guru

Tabel 1

Hasil Pengamatan terhadap Pembelajaran Guru pada Siklus I

\begin{tabular}{|c|c|c|c|c|c|}
\hline \multirow{2}{*}{ No } & \multirow{2}{*}{ Aspek yang dinilai Penilaian } & \multicolumn{4}{|c|}{ Penilaian } \\
\hline & & 1 & 2 & 3 & 4 \\
\hline 1 & Pemberian motivasi belajar & & $\sqrt{ }$ & & \\
\hline 2 & $\begin{array}{l}\text { Kejelasan dan sistematika penyampaian } \\
\text { materi }\end{array}$ & $\sqrt{ }$ & & & \\
\hline 3 & Pengelolaan pembelajaran & $\sqrt{1}$ & & & \\
\hline 4 & Kejelasan suara & & $\sqrt{ }$ & & \\
\hline 5 & Penguasaan bahan & $\sqrt{ }$ & & & \\
\hline 6 & Tuntutan pencapaian/ketercapaian & $\sqrt{ }$ & & & \\
\hline 7 & Memberikan evaluasi kompetensi siswa & $\sqrt{ }$ & & & \\
\hline 8 & Ketepatan strategi pembelajaran & $\sqrt{ }$ & & & \\
\hline
\end{tabular}

. Keterangan:

$1:$ kurang/rendah
$2:$ cukup/sedang

3 : baik/tinggi 
4 : sangat baik/sangat tinggi

Berdasarkan tabel di atas dapat dilihat banyaknya aktifitas mengajar guru yang mendapat nilai 1 (kurang/rendah) yaitu kejelasan dan sistematika penyampaian materi, pengelolaan pembelajaran, penguasaan bahan, tuntutan pencapaian/ketercapaian kompetensi siswa, memberikan evaluasi dan ketepatan strategi pembelajaran. Hasil pengamatan selanjutnya terhadap aktifitas guru yang mendapat nilai 2 (cukup/sedang) yaitu pemberian motivasi belajar dan kejelasan suara.

Pada siklus I dapat disimpulkan bahwa kemampuan guru dalam mengelola kelas masih buruk dilihat dari banyaknya aktifitas mengajar guru yang mendapatkan nilai kurang dan perlu dilakukan perbaikan pada siklus berikutnya. Pada siklus I pada praktek kegiatan pada pelaksanaan rukun wudhu terdapat siswa yang mendapatkan nilai kurang dari 75 (tidak tuntas) sebanyak 18 siswa atau $56 \%$ dari semua siswa kelas II. Hasil siswa yang mendapatkan nilai 75 atau lebih (tuntas) sebanyak 14 siswa atau $44 \%$ dari semua siswa kelas II. Pada siklus I ini dapat disimpulkan bahwa kemampuan siswa dalam mempraktekkan rukun wudhu masih rendah, maka perlu dilakukan perbaikan pada siklus berikutnya.

Berdasarkan data di atas dapat ditampilkan dalam tabel berikut:

Tabel 2

Presentase Ketuntasan Prestasi Belajar Siswa

\begin{tabular}{lllll}
\hline No & Nilai & Jumlah & Presentase & Keterangan \\
\hline 1 & $<75$ & 18 & $56 \%$ & Tidak Tuntas \\
\hline 2 & $\geq 75$ & 14 & $44 \%$ & Tuntas \\
\hline & Total & 32 & & $100 \%$ \\
\hline
\end{tabular}

Berdasarkan tabel di atas, prestasi belajar pada siklus I ditemukan 18 siswa (56\%) tidak tuntas, 14 siswa (44\%) tuntas dalam belajar. Dengan demikian, indikator keberhasilan belajar

Berdasarkan pengamatan pada kondisi siswa selama proses pembelajaran materi rukun wudhu pada siklus I dapat disimpulkan bahwa kondisi siswa kurang baik dalam mengikuti proses pembelajaran, maka perlu ada perbaikan pada siklus berikutnya.

\section{Siklus II \\ Perencanaan}

Dalam perencanaan ini peneliti menyusun RPP. Mempersiapkan fasilitas dan sarana pendukung. Menyiapkan lembar observasi kegiatan guru dan lembar observasi kegiatan peserta didik. ketuntasan siswa sebesar $75 \%$ atau nilai KKM sebesar 75 tidak terpenuhi, jadi observasi kegiatan ini dilanjutkan pada siklus II.

\section{Pelaksanaan}

Guru menjelaskan materi tentang gerakan wudhu dan tata cara melaksanakan sunah wudhu.2)Guru membagi menjadi 8 kelompok, setiap kelompok terdiri dari 4 orang dan diminta untuk memperhatikan contohcontoh gerakan sunah wudhu.3) Guru melakukan evaluasi tentang sunah wudhu.

\section{Observasi}

Dengan instrumen yang telah disiapkan peneliti melakukan pengamatan atau observasi. Hal-hal yang diamati yakni: (1) lembar observasi kegiatan guru 
Tabel 3

Hasil Pengamatan terhadap Pembelajaran Guru pada Siklus II

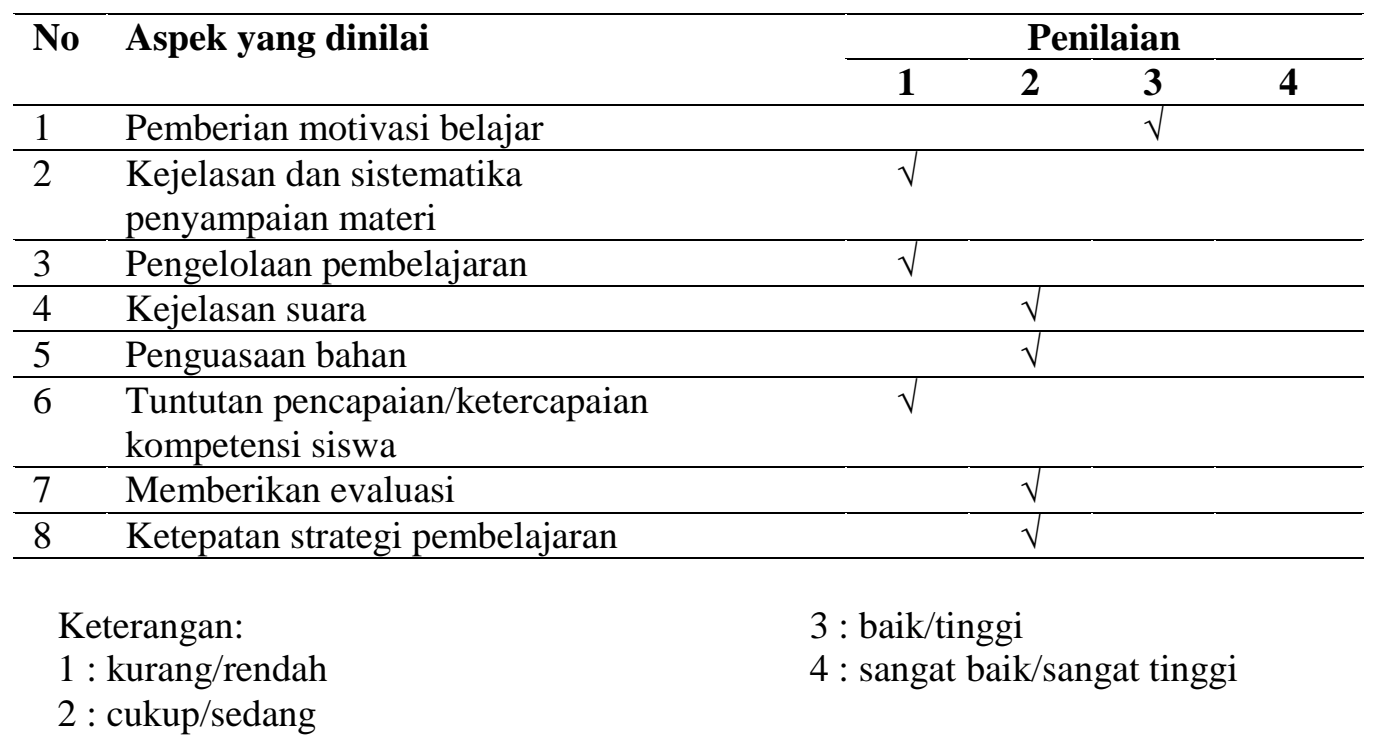

Berdasarkan tabel di atas dapat dilihat banyaknya aktifitas mengajar guru yang mendapat nilai 1 (kurang/rendah) yaitu kejelasan dan sistematika penyampaian materi, pengelolaan pembelajaran, pencapaian/ketercapaian kompetensi siswa. Hasil pengamatan selanjutnya terhadap aktifitas guru yang mendapat nilai 2 (cukup/sedang) yaitu kejelasan suara, penguasaan bahan,memberikan evaluasi dan ketepatan strategi pembelajaran. Hasil pengamatan guru yang mendapat nilai 3 (baik/tinggi) yaitu pemberian motivasi belajar.

Pada siklus II dapat disimpulkan bahwa kemampuan guru dalam mengelola kelas cukup baik dilihat dari banyaknya aktifitas mengajar guru yang mendapatkan nilai cukup. Dari pengamatan terhadap kegiatan siswa pada siklus II tentang sunnah wudhu dapat dilihat siswa yang mendapatkan nilai kurang dari 75 (tidak tuntas) sebanyak 14 siswa atau $44 \%$ dari semua siswa kelas II. Hasil siswa yang mendapatkan nilai 75 atau lebih (tuntas) sebanyak 18 siswa atau $56 \%$ dari semua siswa kelas II. Pada siklus II ini dapat disimpulkan bahwa kemampuan siswa dalam mempraktekkan sunah wudhu sudah cukup baik, namun perlu dilakukan perbaikan pada siklus berikutnya. Berdasarkan data di atas dapat ditampilkan dalam table berikut:

Tabel 4

Presentase Ketuntasan Prestasi Belajar Siswa

\begin{tabular}{lllll}
\hline No & Nilai & Jumlah & Presentase & Keterangan \\
\hline 1. & $<75$ & 14 & $44 \%$ & Tidak Tuntas \\
\hline 2. & $\geq 75$ & 18 & $56 \%$ & Tuntas \\
\hline & Total & 32 & $100 \%$ & \\
\hline
\end{tabular}

Berdasarkan tabel di atas, prestasi belajar pada siklus II ditemukan 14 siswa
(44\%) tidak tuntas, 18 siswa (56\%) tuntas dalam belajar. Dengan demikian, indikator 
keberhasilan belajar ketuntasan siswa sebesar $75 \%$ atau nilai KKM sebesar 75

Pada siklus II hasil pengamatan kondisi siswa selama proses pembelajaran terlihat bahwa siswa yang kurang aktif sebanyak 17 anak atau sebesar 53\%. Siswa yang bermain sendiri sebanyak 13 anak atau sebesar $41 \%$. Siswa yang tidak memperhatikan saat proses pembelajaran sebanyak 17 anak atau sebesar 53\%. Siswa yang masih malu-malu dalam mempraktekkan sunah wudhu sebanyak 18 anak atau sebesar $56 \%$. Siswa yang kurang paham materi sunah wudhu sebanyak 16 anak atau sebesar 50\%. Berdasarkan pengamatan tersebut dapat disimpulkan bahwa kondisi siswa kurang baik dimana siswa yang masih malu-malu dalam mempraktekkan sunah wudhu masih tinggi, sehingga perlu perbaikan pada siklus III.

Siklus III

Perencanaan tidak terpenuhi, jadi observasi kegiatan ini dilanjutkan pada siklus III.

\section{Peneliti menyusun RPP}

a. Mempersiapkan fasilitas dan sarana pendukung. 3)Menyiapkan lembar observasi kegiatan guru dan lembar observasi kegiatan peserta didik. Pelaksanaan

b. Guru menjelaskan materi tentang gerakan wudhu dan tata cara melaksanakan rukun dan sunah wudhu.2)Guru membagi menjadi 8 kelompok, setiap kelompok terdiri dari 4 orang dan diminta untuk memperhatikan contoh-contoh gerakan rukun dan sunah wudhu .3)Guru melakukan evaluasi tentang rukun dan sunah wudhu. Observasi

Dengan instrumen yang telah disiapkan peneliti melakukan pengamatan atau observasi. Hal-hal yang diamati yakni: (1) Lembar observasi kegiatan guru

Tabel 5

Hasil Pengamatan terhadap Pembelajaran Guru pada Siklus III

\begin{tabular}{|c|c|c|c|c|c|}
\hline \multirow[t]{2}{*}{ No } & \multirow[t]{2}{*}{ Aspek yang dinilai } & \multicolumn{4}{|c|}{ Penilaian } \\
\hline & & 1 & 2 & 3 & 4 \\
\hline 1 & Pemberian motivasi belajar & & & & $\sqrt{ }$ \\
\hline 2 & $\begin{array}{l}\text { Kejelasan dan sistematika } \\
\text { penyampaian materi }\end{array}$ & & & $\sqrt{ }$ & \\
\hline 3 & Pengelolaan pembelajaran & & $\sqrt{ }$ & & \\
\hline 4 & Kejelasan suara & & & $\sqrt{ }$ & \\
\hline 5 & Penguasaan bahan & & & $\sqrt{ }$ & \\
\hline 6 & $\begin{array}{l}\text { Tuntutan pencapaian/ketercapaian } \\
\text { kompetensi siswa }\end{array}$ & & & $\sqrt{ }$ & \\
\hline 7 & Memberikan evaluasi & & & $\sqrt{ }$ & \\
\hline 8 & Ketepatan strategi pembelajaran & & & $\sqrt{ }$ & \\
\hline $\begin{array}{l}\text { Ket } \\
1: 1 \\
2: \\
3: b\end{array}$ & $\begin{array}{l}\text { angan: } \\
\text { Irang/rendah } \\
\text { kup/sedang } \\
\text { ik/tinggi }\end{array}$ & \multicolumn{4}{|c|}{ 4: sangat baik/sangat tinggi } \\
\hline
\end{tabular}


Berdasarkan tabel di atas dapat dilihat banyaknya aktifitas mengajar guru yang mendapat nilai 2 (cukup/sedang) yaitu pengelolaan pembelajaran. Hasil pengamatan selanjutnya terhadap aktifitas guru yang mendapat nilai 3 (baik/tinggi) yaitu kejelasan dan sistematika penyampaian materi, kejelasan suara, penguasaan bahan, tuntutan pencapaian/ketercapaian, memberikan evaluasi dan ketepatan strategi pembelajaran. Hasil pengamatan guru yang mendapat nilai 4 (sangat baik/sangat tinggi) yaitu pemberian motivasi belajar. Pada siklus III dapat disimpulkan bahwa kemampuan guru dalam mengelola kelas sudah baik dilihat dari banyaknya aktifitas mengajar guru yang mendapatkan nilai baik.

1) Lembar observasi kegiatan peserta didik dengan materi praktek rukun dan sunah wudhu. Dari pengamatan terhadap kegiatan siswa pada pembelajaran rukun wudhu pada siklus III dapat dilihat siswa yang mendapatkan nilai kurang dari 75 (tidak tuntas) sebanyak 6 siswa atau 19\% dari semua siswa kelas II. Hasil siswa yang mendapatkan nilai 75 atau lebih (tuntas) sebanyak 26 siswa atau $81 \%$ dari semua siswa kelas II. Pada siklus III ini dapat disimpulkan bahwa kemampuan siswa dalam mempraktekkan rukun wudhu sudah baik.

Berdasarkan data di atas dapat ditampilkan dalam table berikut:

Tabel 6

Presentase Ketuntasan Prestasi Belajar Siswa

\begin{tabular}{lllll}
\hline No & Nilai & Jumlah & . Presentase & Keterangan \\
\hline 1 & $<75$ & 6 & $19 \%$ & Tidak Tuntas \\
\hline 2 & $\geq 75$ & 26 & $81 \%$ & Tuntas \\
\hline & Total & 32 & $100 \%$ & \\
\hline
\end{tabular}

Berdasarkan tabel di atas, prestasi belajar pada siklus III ditemukan 6 siswa $(19 \%)$ tidak tuntas, 26 siswa (81\%) tuntas dalam belajar. Dengan demikian, indikator keberhasilan belajar ketuntasan siswa sebesar $75 \%$ atau nilai KKM sebesar 75 sudah terpenuhi, jadi siklus dihentikan. Sebanyak 6 siswa (19\%) yang tidak tuntas belajar dilakukan remidi secara individual di luar jam yang dijadwalkan.

Dari pengamatan kegiatan pembelajaransunnah wudhu siswa pada

siklus III dapat dilihat siswa yang mendapatkan nilai kurang dari 75 (tidak tuntas) sebanyak 4 siswa atau 12,5\% dari semua siswa kelas II. Hasil siswa yang mendapatkan nilai 75 atau lebih (tuntas) sebanyak 28 siswa atau $87,5 \%$ dari semua siswa kelas II. Pada siklus III ini dapat disimpulkan bahwa kemampuan siswa dalam mempraktekkan sunah wudhu sudah baik.

Berdasarkan data di atas dapat ditampilkan dalam tabel berikut:

Tabel 7

Presentase Ketuntasan Prestasi Belajar Siswa

\begin{tabular}{lllll}
\hline No & Nilai & Jumlah & . Presentase & Keterangan \\
\hline 1 & $<75$ & 4 & $12,5 \%$ & Tidak Tuntas \\
\hline 2 & $\geq 75$ & 28 & $87,5 \%$ & Tuntas \\
\hline & Total & 32 & $100 \%$ & \\
\hline
\end{tabular}

Berdasarkan tabel di atas, prestasi $(12,5 \%)$ tidak tuntas, 28 siswa $(87,5 \%)$ belajar pada siklus III ditemukan 4 siswa tuntas dalam belajar. Dengan demikian, 
indikator keberhasilan belajar ketuntasan siswa sebesar $75 \%$ atau nilai KKM sebesar 75 sudah terpenuhi, jadi siklus dihentikan. Sebanyak 4 siswa $(12,5 \%)$ yang tidak tuntas belajar dilakukan remidi secara individual di luar jam yang sudah dijadwalkan.

Berdasarkan hasil pengamatan tentang kondisi siswa selama proses pembelajaran pada materi rukun wudhu dan sunnah wudhu pada siklus III bahwa kondisi siswa dalam mengikuti proses pembelajaran rukun dan sunah wudhu sudah sangat baik dengan ditunjukkan semua siswa sudah tidak bermain sendiri, memperhatikan materi yang disampaikan guru dan sudah tidak malu-malu untuk mempraktekkan rukun dan sunah wudhu. Dengan demikian dapat disimpulkan bahwa ada peningkatan kondisi siswa selama proses pembelajaran berlangsung dengan menggunakan metode demonstrasi.

\section{Pembahasan Hasil Penelitian}

Penggunaan metode demonstrasi pada mata pelajaran PAI sangat membantu dalam pemahaman siswa khususnya materi rukun dan sunah wudhu. Dalam proses pembelajaran dengan menggunakan metode demonstrasi, guru menjelaskan materi dengan menunjukkan contoh gerakangerakan rukun dan sunah wudhu pada gambar, sehingga siswa akan lebih melekat dan memahami. Pembelajaran PAI tidak hanya hafalan tetapi harus benar-benar memahami materi yang diajarkan.

Kegiatan selanjutnya guru melakukan tanya jawab kepada siswa sehingga memungkinkan siswa untuk memperbaiki pemahaman yang salah tentang materi rukun dan sunah wudhu. Selain itu, metode ini juga membuat pembelajaran lebih jelas dan bervariasi. Penelitian tindakan kelas dengan menggunakan metode demonstrasi ternyata membuahkan hasil dan akibat yang baik. Hal ini dapat dilihat dari hasil pengamatan yang dilakukan oleh peneliti.

Berdasarkan pada siklus I jumlah siswa yang tuntas belajar sebanyak 14 anak, sedangkan pada siklus II jumlah siswa yang tuntas belajar sebanyak 18 anak. Pada siklus III untuk materi rukun wudhu jumlah siswa yang tuntas belajar sebanyak 26 anak, sedangkan untuk materi sunah wudhu siswa yang tuntas belajar sebanyak 28 anak. Hal ini menunjukkan bahwa dari siklus I sampai dengan siklus III ketuntasan dalam belajar selalu meningkat. Dari hasil tersebut dapat disimpulkan bahwa dengan menggunakan metode demonstrasi dapat meningkatkan prestasi belajar siswa pada mata pelajaran PAI.

\section{KESIMPULAN DAN SARAN Kesimpulan}

Metode demonstrasi pada pembelajaran PAI dapat meningkatkan prestasi belajar siswa kelas II SDN 1 Sukadana, Kecamatan Secang, Kabupaten Magelang Tahun 2012. Prestasi belajar pada siklus I sebesar $44 \%$ atau 14 siswa dengan KKM 75, siklus II sebesar 56\% atau 18 siswa dengan KKM 75 dan pada siklus III sebesar $81 \%$ atau 26 siswa untuk materi rukun wudhu dan sebesar $87,5 \%$ atau 28 siswa untuk materi sunah wudhu dengan KKM 75. Peningkatan prestasi belajar siswa pada siklus I ke siklus II sebesar 12\% dengan KKM 75, peningkatan prestasi pada siklus II ke siklus III dengan materi rukun wudhu sebesar $25 \%$ dan pada materi sunah wudhu sebesar $31,5 \%$.

\section{Saran}

Berdasarkan hasil penelitian tindakan kelas yang diperoleh maka terdapat beberapa saran sebagai berikut: (1) Bagi Guru, dalam pelaksanaan pembelajaran mata pelajaran PAI selain menggunakan metode ceramah atau penugasan 
sebaiknya juga dapat menggunakan metode demonstrasi terutama menyangkut materi yang membutuhkan metode ini agar prestasi belajar siswa dapat meningkat. (2) Bagi Siswa, dalam proses pembelajaran sebaiknya siswa tidak malu untuk bertanya tentang materi yang belum jelas dan siswa juga tidak malu untuk mempraktekkan materi rukun dan sunah wudhu, sehingga siswa dapat memperoleh hasil yang maksimal. (3) Bagi Sekolah, hendaknya menyiapkan fasilitas untuk para guru yang akan melakukan penelitian tindakan kelas agar terwujud sekolah yang bermutu dan berkualitas dalam menghadapi kemajuan di dunia pendidikan.

\section{DAFTAR RUJUKAN}

Arifin, Zaenal. 2000. Evaluasi Instruksional. Bandung: Remaja Rosda Karya.
Arikunto, Suharsimi. 2006. Penelitian Tindakan Kelas. Jakarta: Bumi Aksara.

Djamarah, Syaiful Bahri. 2000. Guru dan Anak Didik Dalam Interaksi Edukatif. Jakarta: Rineka Cipta.

Poerwardarminta. 2006. Kamus Umum Bahasa Indonesia. Departemen

Pendidikan Nasional Edisi III Cet 3. Jakarta: Balai Pustaka.

Sabiq. 2006. Fiqh Sunah. Jakarta: Pundi Aksara.

Slameto. 1991. Belajar dan Faktor-faktor yang Mempengaruhi. Bandung: Rineka Cipta.

Syah, Muhaibin. 1995. Psikologi Pendidikan. Bandung: Rineka Cipta.

Zaenal, Aqib. 2006. Penelitian Tindakan Kelas. Bandung: Irama Widya. (http://educassi.kompasiana.com.pros es-da-prinsip-dalam-belajar. Diakses 19.00. tanggal 10/12/2015) 